\title{
Characterization of Groundwater Zones and Salinity Assessment in Aquifers of the Campo District, South Cameroon Using the GIS, AHP and PCA Approach.
}

Kouamou Njifen Serges Raoul ( $\nabla$ kouamousergeraoul@yahoo.fr )

University of Yaounde I: Universite de Yaounde I

Eyengue A Nyam Francoise

University of Yaounde I: Universite de Yaounde I

Fossi Donald Hermann

University of Yaounde I: Universite de Yaounde I

Bikoro Bi-Alou Marcelin

University of Yaounde I: Universite de Yaounde I

Ngouokouo Tchikangoua Anita

University of Yaounde I: Universite de Yaounde I

Bounoung Clement Parfait

University of Yaounde I: Universite de Yaounde I

Tabod Charles Tabod

University of Yaounde I: Universite de Yaounde I

\section{Research Article}

Keywords: Groundwater, GIS, AHP, PCA, Mineralization

Posted Date: January 10th, 2022

DOI: https://doi.org/10.21203/rs.3.rs-1196842/v1

License: @ (i) This work is licensed under a Creative Commons Attribution 4.0 International License.

Read Full License 


\section{Characterization of groundwater zones and salinity assessment in aquifers of the Campo district, South Cameroon using the GIS, AHP and PCA approach.}

Kouamou Njifen Serges Raoul ${ }^{1 *}$, A Nyam Eyengue Francoise ${ }^{1 *}$, Fossi Donald Hermann ${ }^{2}$, Bikoro Bi-Alou Marcelin ${ }^{4}$, Ngouokouo Tchikangoua Anita ${ }^{1}$, Bounoung Clement Parfait ${ }^{1}$, Tabod Charles Tabod ${ }^{1,3}$

${ }^{1}$ Department of Physics, University of Yaoundé I, P.O. Box 812 Yaoundé, Cameroon

${ }^{2}$ Centre for Research in Space Imagery (CRIS), Institute for Geological and Mining Research (IRGM) P.O. Box 4110 Yaoundé, Cameroon

${ }^{3}$ Department of Physics, Faculty of Science, University of Bamenda, Box 39 Bambili, Cameroon.

${ }^{4}$ Department of Applied Geophysics, Geology and Mining Exploitation College, University of Ngaoundéré, 455 Ngaoundéré, Cameroon.

*Corresponding authors: kouamousergeraoul@yahoo.fr (Kouamou Serges), francem2019@yahoo.com (Eyengue A Nyam F M).

\section{Abstract}

In the Campo region, groundwater is critical for human consumption and social activity. Groundwater potential is influenced by a region's geological, geophysical, and hydrogeological factors. The major goals of this research are to determine which regions are ideal for productive groundwater drilling and to assess the source of salinity in the study area's coastal aquifers. The groundwater potential map was created using Geographic Information Systems (GIS) and the Hierarchical Analysis Process (AHP). The process of groundwater mineralization was studied using principal component analysis (PCA). Six variables were taken into account, and weights were assigned to them based on their impact on groundwater recharge. In a GIS environment, spatial integration and a combination of theme layers were conducted. Campo's groundwater potential map was divided into four zones: low $14.4 \%\left(389.6 \mathrm{~km}^{2}\right)$, moderate $53.3 \%(1484.5$ $\left.\mathrm{km}^{2}\right)$, high $28.3 \%\left(783.3 \mathrm{~km}^{2}\right)$, and extremely high $4.1 \%\left(110.9 \mathrm{~km}^{2}\right)$. The results of the PCA reveal a mechanism of water-rock interaction, as a result of geological alteration and a salinization process caused by the intrusion of seawater and human activity The source of salinity in groundwater is manmade (agricultural and residential activities) rather than seawater intrusion. Seawater infiltration is not greatly aided by the low lineament density found near the beaches. 
Keywords: Groundwater, GIS, AHP, PCA, Mineralization.

\section{Introduction}

Drinking water is a basic requirement for the people of southern Cameroon, and its lack poses a major threat to the health of both urban and rural residents. Cameroon's state business in charge of drinking water distribution is having huge challenges supplying the population with clean water. The primary cause is a scarcity of financial and human resources. To deal with this pressing issue, the people of Cameroon's Campo region, located in the south, rely on surface and subsurface water for the household, agricultural, and industrial needs. The importance of groundwater is crucial, as it is the primary source of supplies for the Campo region's residents. Groundwater has become an important supply of water, and many studies have been conducted on it around the world (Arefin, 2020; Murmu et al., 2019; Singh et al., 2018). The current research focuses on the identification of possible groundwater resources as well as the impact of the sea and human activities on salinity in coastal aquifers in the Campo region. In coastal places, shallow aquifers are subjected to a lot of saltwater intrusion (Dhakate et al., 2016). The salinity of groundwater in coastal locations is increasing as sea levels rise due to global warming (Aretouyap et al., 2020). Water salinity is influenced by human activity, natural occurrences, and the geological nature of the land (Masoud et al., 2018; Dhakate et al., 2016). In a coastal zone, high amounts of salt in groundwater have negative repercussions for residents, agricultural, and industrial activity (Hounsinou, 2020). To better understand the geological features of southern Cameroon, numerous geophysical and geological research have been conducted (Aretouyap et al., 2020; Joseph Martial et al., 2019; Nguiya et al., 2019). These studies have permitted the detection of aquifers and the discovery of geoelectric sections (José et al., 2021; Tepoule, Kenfack et al., 2021). During the wet season, the intense and uncontrolled use of agricultural inputs and manures hurts groundwater quality. Understanding the processes and conditions that influence groundwater quality is critical for sustainable water resource 
management (Enyegue A Nyam et al., 2020; S. Kumar \& Sangeetha, 2020; Abbasnia et al., 2019; Beyene et al., 2019). (Tsaffo Mbognou et al., 2021; Tepoule et al., 2021; Arétouyap et al., 2018; Teikeu Assatse et al., 2016a) demonstrate that little study has been done in Cameroon to quantify freshwater potential using geospatial methodologies. The Kribi-Campo region lineaments have previously been researched to better understand spatial changes, hearing, and its impact on seawater intrusion into groundwater (Aretouyap et al, 2020). To designate possible groundwater zones from conventional and remote sensing data, numerous characteristics that influence groundwater recharge were taken into account for this study. To find appropriate groundwater locations, much recent research has incorporated Analytical Hierarchy Process (AHP), Geographic Information System (GIS), and remote sensing approaches (Arunbose et al., 2021; Ajay Kumar et al., 2020; Kulandaisamy et al., 2020). AHP is a multi-criteria decisionmaking methodology (Saaty, 1990) that is frequently used to assess groundwater potential locations (Dar et al., 2020; Saranya \& Saravanan, 2020; Das, 2019; Muralitharan \& Palanivel, 2015; T. Kumar et al., 2014). To explain the origins of groundwater mineralization, several researchers have relied heavily on physicochemical factors (Enyegue A Nyam et al., 2020; Bodrud-Doza et al., 2016; Dewandel et al., 2006). Principal component analysis (PCA), which is a type of multivariate statistical analysis, is to be effective in identifying and understanding the sources of salinity in groundwater and soils. (Marín Celestino et al., 2018; Masoud et al., 2018; Muangthong \& Shrestha, 2015). The study's main goals are to map the favourable areas for sitting productive boreholes using GIS and AHP and use PCA to understand the process and mechanism related to the origin of salinity in the study area's aquifers. The research will aid in planning, health protection for residents, and long-term freshwater management in the Campo area, as well as conservation of this vital resource.

\section{Study area.}

Campo district is located in Cameroon's southern area, between latitudes $2^{\circ} 22^{\prime}$ and $2^{\circ} 73^{\prime}$ and longitudes $9^{\circ} 80^{\prime}$ and $10^{\circ} 61^{\prime}$, at an elevation of 7 to 518 meters above the geoid. The Campo 
region is a coastal area with a land area of approximately $2769.7 \mathrm{~km}^{2}$ (Fig. 1). The research area is surrounded by a thick hydrographic network that originates in the Atlantic basin. The climate in this area is tropical Guinean, with four distinct and unequal seasons: a long dry season from November to March (Fig. 2), a rainy season from April to June, a relatively dry July, and a fresh rainy season from mid-August to the end of October. With an average rainfall of $434.4 \mathrm{~mm}$ and an average annual temperature of $24.9^{\circ} \mathrm{C}$, October is the wettest month. The yearly average rainfall is $2294.4 \mathrm{~mm}$, and the annual average temperature is $25.7^{\circ} \mathrm{C}$. The Kribi-Campo subbasin, which is characterized by sedimentary strata and metamorphic bedrock, also includes the Campo region. Limestones, shales, and sandstones characterize the Cretaceous-Cenozoic sedimentary formations (Aretouyap et al., 2020; Agyingi et al., 2019). Gneiss, mica schists, and granites make up the basement, which is made up of gneiss and metamorphic rocks from the Precambrian epoch (Joseph Martial et al., 2019; Tchameni et al., 1996; Ndema Mbongue et al., 2014). Campo's vegetation is naturally diversified, with a dense and varied flora impacted by its proximity to the sea. From a hydrogeological standpoint, the aquifer of the alterations contained in the saturated zones of the subsoil and the aquifer of the fractures coexist in the various sites of the region, as they do in all regions with crystalline subsoil. Ferritic and ferruginous soils are the most common soil types in the area.

\section{Methodologies.}

\subsection{Thematic layer selections.}

Criteria were chosen and analyzed based on their aquifer recharge implications. Using remote sensing and conventional data, six layers (lithology, lineament density, infiltration rate, drainage density, slope, land use/land cover) were developed and integrated into a GIS context to designate areas with groundwater potential. To evaluate the selection of groundwater recharge criteria, geological features, lithological units, geological structures, precipitation infiltration rate, and surface runoff were taken into account.

The World Geodetic System (WGS 1984) was georeferenced and translated to vector format in a GIS environment, and all layers were projected to UTM, zone $32 \mathrm{~N}$.

\subsection{Data acquisition and preparation of thematic layers.}

\subsubsection{Lithology}


Because infiltration is often dependent on the porosity and permeability of certain rock types, lithology is the most influential factor in groundwater recharge (Abijith et al., 2020; Murmu et al., 2019;). Groundwater infiltration and flow mechanisms are heavily influenced by lithology (Allafta et al., 2021). Some studies evaluate lineament densities and drainage networks as a function of primary and secondary porosity rather than lithology when examining parameters that influence groundwater recharge (Yeh et al., 2016). The lithological map was created by digitizing Cameroon's geological map (Scale 1: 500000).

\subsubsection{Lineament's density}

The lineament density map was created using ArcGis 10.7 software and data from the Shuttle Radar Topography Mission's digital terrain model (DEM). The DEM data was obtained from the (http://srtm.csi.cgiar.org) website. Eight shaded relief photos were obtained with a constant source tilt of $45^{\circ}$ from the horizontal and eight different azimuth angles $\left(0^{\circ}, 45^{\circ}, 60^{\circ}, 100^{\circ}\right.$, $140^{\circ}, 170^{\circ}, 230^{\circ}$, and $315^{\circ}$ ) to obtain the lineaments. Shaded relief (SR) is a two-dimensional depiction of the topography of an earth surface that may be calculated using equation (1) (Serebryakova et al., 2015):

$\mathrm{RO}=255[\cos (\mathrm{Z}) \cdot \cos (\mathrm{Sl})]+[\sin (\mathrm{Z}) \cdot \sin (\mathrm{Sl}) \cdot \cos (\mathrm{Az}-\mathrm{As})]$

Where $\mathrm{Sl}$ is the slope of the terrain, $\mathrm{Az}$ is the azimuth or direction of the light vector, As is the aspect of the image, $\mathrm{Z}$ is the angle of inclination above the horizon of the light vector.

To avoid considering auxiliary data during extraction, the manually extracted lineaments were overlaid with auxiliary data such as roadways and runways (Serele et al., 2020; Teikeu Assatse et al., 2016b). The lineaments retrieved from the shaded relief were further supplemented by tectonic lineaments (faults) from the geological map of the area. Equation (2) was used to construct the density map of the lineaments using the ArcGis 10.7 software's density line tool. (Greenbaum, 1985):

$$
\mathrm{L}_{\mathrm{d}}=\frac{\sum_{i=1}^{n} L_{i}}{A}
$$

Where $\sum_{i=1}^{n} L_{i}$ is the total length of the lineaments $(\mathrm{km})$ and $\mathrm{A}$ is the area unit $\left(\mathrm{km}^{2}\right)$.

\subsubsection{Drainage density}

Drainage density is a quantitative measure of channels per unit area that also shows the link between surface runoff and soil permeability (Fossi et al., 2021; Achu et al., 2020; Kanagaraj et al., 2019; Takodjou Wambo et al., 2018). The drainage density map was created using the digital terrain model's drainage network. The DEM data was used to construct the drainage 
density map, which was calculated using the following equation (Greenbaum, 1985; HORTON, 1945):

$$
\mathrm{D}_{\mathrm{d}}=\frac{\sum_{i=1}^{n} D_{i}}{A}
$$

Where $\sum_{i=1}^{n} D_{i}$ total length of the drainage $(\mathrm{km})$ and $\mathrm{A}$ is the unit of area $\left(\mathrm{km}^{2}\right)$.

\subsubsection{Infiltration rate.}

The infiltration rate is the amount of water that percolates into the soil in a given amount of time. When the rainfall intensity is less than the infiltration capacity, the rain infiltrates into the soil. The phenomena that control the passage of water to the soil surface control the infiltration process (Ibrahim-Bathis \& Ahmed, 2016). The infiltration process regulates runoff, soil wetness, and percolation. The density of drainage and the frequency of watercourses are also proportional to the rate of infiltration (FANIRAN, 1969). Stream frequency is defined as the ratio of all streams of a given order in a research area to the study area's area equation (4) (Arefin, 2020; HORTON, 1945). Using the infiltration number obtained from equation (5), an infiltration rate map was created:

$$
\begin{aligned}
\mathrm{S}_{\mathrm{f}} & =\frac{N_{S}}{A} \\
\mathrm{IR} & =\mathrm{D}_{\mathrm{d}} \times \mathrm{S}_{\mathrm{f}}
\end{aligned}
$$

Where, IR = infiltration rate, $S_{\mathrm{f}}=$ Stream frequency; $N s=$ Total number of stream segments of all orders; $A$ = area of the study area.

\subsubsection{The slope}

When it comes to groundwater recharge, the slope is crucial. Rainfall and surface runoff infiltration are aided by low slopes. Yeh et al. (2016) found that the angle of the slope has a substantial impact on rainfall infiltration, with the higher the angle, the higher the runoff and the lower the infiltration (Abijith et al., 2020). Equation (6) (SCHUMM, 1968) describes the algorithm for computing the slope:

$$
\mathrm{S}_{\mathrm{b}}=\frac{H}{L_{b}}
$$

Where $\mathrm{H}$ denotes the elevation difference between two points and $\mathrm{L}_{b}$ is the distance between two points.

\subsubsection{Land use/land cover}


Groundwater recharge is influenced by some factors, including land use. The Landsat 8 OLI image was obtained from the Earth Explorer website of the United States Geological Survey (www.earthexplorer.usgs.gov). ERDAS imagine and ArcGIS software was used to extract the land use/land cover map from the Landsat picture. In the study region, four land use groups were extracted using supervised classification: primary vegetation, water bodies, agriculture, and built-up areas.

\subsection{Weight assignment and weight normalization using AHP.}

The final weights of the various layers and classes were determined using the following steps: criteria identification, classification, weighing of criteria and sub-criteria, normalizing of weights, and verifying the consistency of the resulting solution. According to the relative relevance of one criterion to the other, the AHP requires a pairwise comparison matrix (Table 1) of the different criteria using a suitable Saaty scale (Table 2). The most significant aspect of the decision analysis (Saaty, 1990) is assigning the right weight to each criterion and its characteristics because the outcome is primarily dependent on it (Soyaslan, 2020). To create a single scale, the weights allocated to the various parameters and their classes were standardized. The eigenvalue is determined using the eigenvectors of each of the criteria and their features once the standardized matrix has been formed. The eigenvalue $\left(\lambda_{\max }\right)$ is used to determine whether the solution produced is consistent. The following equations were used to determine the consistency index and consistency ratio. Saaty (Saaty, 1990):

$$
C I=\frac{\lambda \max -n}{n-1}
$$

Where $\mathrm{n}=$ number of criteria used.

$$
\operatorname{Cr}=\frac{C I}{R I}
$$

The consistency ratio, $\mathrm{Cr}=0.02$, is considered acceptable, as its value is less than 0.1 . RI is the random inconsistency and its values are presented in Table 3.

\subsection{Assessment and validation of favourable groundwater zones}

The Groundwater Potential Indices were created by multiplying the normalized class weights resulting from the AHP by the weight of each layer equation (9) to discover the favourable groundwater locations (GWPI). 


$$
\mathrm{GWPI}=\sum_{i=1}^{n} W_{i} R_{i}
$$

Where, GWPI = Groundwater Potential Index, Wi and Ri are the criteria weights and class weights in the layers respectively. The groundwater potential map was validated using data from fifteen boreholes provided by the China Geo-Engineering Corporation in Cameroon (GSC-CAM) to ensure the accuracy of our findings.

\subsection{Sensitivity analyses.}

After the groundwater potential map has been obtained, sensitivity analysis can be used to assess the correctness of the results. The influence of each criterion on the groundwater potential map can also be observed through sensitivity analysis (Ajay Kumar et al., 2020). This study looked at two forms of sensitivity analyses: the map removal sensitivity analysis by map removal and the single parameter sensitivity analysis. The first kind conducts a statistical analysis of the data using a sensitivity index produced by subtracting an individual layer from the groundwater potential map using equation (10) (Sinha et al., 2016). The second step is to use equation (11) to assess the impact of each of the criteria on the groundwater potential index.

$$
\mathrm{S}=\frac{\left|\frac{G W P I}{N}-\frac{G W P I^{\prime}}{n}\right|}{G W P I} \times 100
$$

Where $\mathrm{N}=$ total number of parameters, $\mathrm{n}=$ number of remaining parameters and GWPZ' $=$ Groundwater Potential Zone after removing a parameter.

$$
\mathrm{V}=\frac{W_{i} R_{i}}{G W P I} \times 100
$$

Where Wi and Ri are the layer weights and the class weights of different layers. Figure 3 describes the set of methods used in this study.

\subsection{Groundwater sample analyses and multivariate statistics.}

To comprehend the evolution of physicochemical characteristics in space, the Inverse Distance Weighted (IDW) spatial interpolation approach was utilized to highlight their spatial distribution. The pre-processing of the data and the comprehension of the relationships between the physicochemical characteristics and the similarities between the groundwater boreholes using the PCA method are the two primary steps of the multivariate statistical analysis methodology. The statistical analysis was carried out using Python 3.7 and the Scikit-Learn Package for the necessary calculations, although we were responsible for all post-processing, particularly the interpretation aids. A dataset of 15 water samples with 5 physicochemical variables was used in the statistical analysis. Furthermore, PCA is an extremely sensitive 
approach to extreme values. Because of the great sensitivity to extreme values, PCA must be applied on reduced centered or normalized data (Eq. 12), which gives each variable the same weight (Loh et al., 2020).

$$
\mathrm{Z}=\frac{x-\mu}{\sigma}
$$

Where $\mathrm{Z}$ is the normalized value, $x$ is the data. $\mu$ and $\sigma$ are the mean and standard deviation respectively. PCA is a multidimensional statistical method for summarizing the information in the data. We calculated the contribution for the interpretation aid. It enables us to identify the most important observations in the definition of each factor. The biggest contribution is made by an element with a strong coordinate, which is indicated as a percentage.

\subsection{Results.}

The final individual class weights for all layers and their consistency ratios are presented in Table 4.

\subsubsection{Lithology.}

Aquifer recharge is influenced by rocks having high porosity and permeability (Ghorbani Nejad et al., 2017). Groundwater infiltration, transport, and recharge are not possible in highly resistant rock formations. The research area's geological map is defined by many geological units, including sedimentary cover, micaschist, gneiss and amphibolite, gneiss and TTG, and charnockitic suite, which cover 60.3 (0.5\%), 131.6 (1.1\%), 998 (34.5\%), 342.3 (2.7\%), and $1210.8(44.3 \%) \mathrm{km}^{2}$ respectively (Fig. 4a). The sedimentary cover was given the highest rank because of their high porosity rates and the charnockitic suite core, which are very resistant rocks.

\subsubsection{Lineament's density.}

Groundwater recharge is greatly aided by high lineament density (Arunbose et al., 2021). The density of lineaments ranges from 0 to $8.9 \mathrm{~km} / \mathrm{km}^{2}$ (Fig. 4b). The study area's lineament density was divided into five categories: very high $\left(5.24-8.9 \mathrm{~km} / \mathrm{km}^{2}\right)$, high $\left(5.24-3.16 \mathrm{~km} / \mathrm{km}^{2}\right)$, moderate $\left(3.16-1.75 \mathrm{~km} / \mathrm{km}^{2}\right)$, low $\left(1.75-0.63 \mathrm{~km} / \mathrm{km}^{2}\right)$, and very low $\left(0-0.63 \mathrm{~km} / \mathrm{km}^{2}\right)$, covering 44.9 (1.6\%), $206.6(7.5 \%), 448.2(16.4 \%), 645.3(23.6 \%)$, and $1392.2(50.7 \%) \mathrm{km}^{2}$ respectively. The very high class received the highest rank.

\subsubsection{Infiltration rate.}


The rate of infiltration is influenced by soil texture and porosity, both of which aid in the movement of surface water. The study area's infiltration rate map was divided into five categories: very low $(0.011-0.23 \mathrm{~mm} / \mathrm{h})$, low $(0.23-0.34 \mathrm{~mm} / \mathrm{h})$, moderate $(0.34-0.5 \mathrm{~mm} / \mathrm{h})$, high $(0.5-0.75 \mathrm{~mm} / \mathrm{h})$, and very high $(0.75-1.54 \mathrm{~mm} / \mathrm{h})$, which accounted for $999.2(36.5 \%)$, 1165.3 (42.3\%), 440.2 (16.1\%), 120.1 (4.4\%), and 19.2 (0.7\%) km² (Fig. 4c). The extremely high category received the highest ranking. Groundwater recharging is aided by a high infiltration rate (Ibrahim-Bathis \& Ahmed, 2016).

\subsection{Drainage density.}

The distribution of runoff and infiltration rate is controlled by drainage density, which is one of the most fundamental indicators in hydrogeology (Ibrahim-Bathis \& Ahmed, 2016). Percolation is increased when drainage density increases, resulting in low groundwater recharge (Nasir et al., 2018). The drainage density in the studied area ranges from 0 to $6.55 \mathrm{~km} / \mathrm{km}^{2}$ (Fig. 4d). The drainage density map of the study area was also reclassified into five distinct classes: very low $\left(0-0.66 \mathrm{~km} / \mathrm{km}^{2}\right)$, low $\left(0.66-1.46 \mathrm{~km} / \mathrm{km}^{2}\right)$, moderate $\left(1.46-2.34 \mathrm{~km} / \mathrm{km}^{2}\right)$, high $(2.34$ - $\left.3.52 \mathrm{~km} / \mathrm{km}^{2}\right)$, and very high (3.52-6.55 km/ $\left.\mathrm{km}^{2}\right)$, with $835.5(30.3 \%), 759.2(28.6 \%), 662.5$ $(24 \%), 374.5(13.5 \%) \mathrm{km}^{2}$, and the very low class received the highest rank.

\subsubsection{The slope.}

The slope of a region's groundwater recharge is a critical issue. As indicated in Figure 4e, the study area was separated into five sub-areas based on their slopes: very low $\left(0^{\circ}-4^{\circ}\right)$, low $\left(4^{\circ}\right.$ $\left.10^{\circ}\right)$, moderate $\left(10^{\circ}-20^{\circ}\right)$, high $\left(20^{\circ}-30^{\circ}\right)$, and very high $\left(>30^{\circ}\right)$, each occupying 1627.2 (59.8\%), 578.7 (21.9\%), $369.3(13.5 \%), 111.1(4.2 \%)$, and $12.3(0.5 \%) \mathrm{km}^{2}$. The very lowgrade area received the greatest rank, while the very high-grade class received the lowest weight.

\subsubsection{Land Use/Land Cover (LULC).}

Controlling infiltration and surface runoff is influenced by the type of land used (Ajay Kumar et al., 2020). Primary vegetation accounts for 2343.9 (85.5\%), water bodies 31.3 (1.2\%), agriculture $210.1(7.6 \%)$, and built-up areas $152.1(5.5 \%) \mathrm{km}^{2}$ in the research region, respectively (Fig.4f). Due to the lack of permeable surfaces in built-up areas, surface water infiltration is reduced (Allafta et al., 2021). Built-up regions were given the final place because of their high-water retention capacity. Water bodies were given first place, followed by agriculture and main vegetation.

\section{4-2. Physicochemical characterization of groundwater}


Table 5 shows the findings of the physicochemical parameter study based on World Health Organization standards (WHO 2011). The regional distribution of physicochemical parameters is depicted in Figures 5a-e.

The contact of groundwater with the rock structures it passes through is the primary cause of water hardness (Beyene et al., 2019). It is a measure of the amount of limestone in the water, and it corresponds to the amount of calcium and magnesium in the water. The total hardness in the Campo region varies between $14{ }^{\circ} \mathrm{F}$ and $15^{\circ} \mathrm{F}$, with an average of $14.5^{\circ} \mathrm{F}$ and a standard deviation of $0.5^{\circ} \mathrm{F}$; these slight differences in total hardness are primarily attributable to the change of sedimentary rocks and limestone minerals. The total alkalinity of groundwater is the result of rock mineral change, soil leaching, and precipitation inputs to the atmosphere. It ranges from 3 to $3.7 \mathrm{mmol} / \mathrm{l}$, with an average of $3.4 \mathrm{mmol} / \mathrm{l}$ and $0.2 \mathrm{mmol} / \mathrm{l}$ standard deviation. Low variations are found in the western samples (W10, W14, and W13) near the sea, and can be attributed to some factors, including the precipitation of calcite $(\mathrm{CaCO} 3)$, which lowers alkalinity, and rocks containing bicarbonate and hydroxide compounds. Calcium concentrations range from 45 to $52 \mathrm{mg} / \mathrm{l}$, with a mean of $49.4 \mathrm{mg} / \mathrm{l}$ and $1.8 \mathrm{mg} / \mathrm{l}$ standard deviation. The heavy agricultural activities, surface water infiltration, and geological components of the research area (Enyegue A Nyam et al., 2020), could all contribute to the elevated $\mathrm{Ca}^{2+}$ concentrations in the east (W3) and north (W11 and W12) of the study area. Magnesium levels range from 6 to 18 $\mathrm{mg} / \mathrm{l}$, with an average of $9.3 \mathrm{mg} / \mathrm{l}$ and a standard deviation of $3.1 \mathrm{mg} / \mathrm{l}$. The magnesium in the groundwater could be the result of dolomite dissolution and a substitution phenomenon between the magnesium released by total alkalinity and the magnesium released by the dolomite. The alkalinity of water is largely determined by hydrogen carbonate. The concentrations of hydrogen carbonate range from 195.2 to $225.8 \mathrm{mg} / \mathrm{l}$, with an average of $210.5 \mathrm{mg} / \mathrm{l}$ and a standard deviation of $11.5 \mathrm{mg} / \mathrm{l}$. The drill samples (W3, W4, W14, and W8) likewise had low values, which could be due to the sedimentary deposits.

\subsection{Multivariate statistical analysis.}

4.3.1. Correlation between physicochemical parameters of groundwater. 
Figure 6 shows the relationships between the physicochemical properties of groundwater. Total hardness has a positive relationship with magnesium, hydrogen carbonates, and total alkalinity. These numbers illustrate how important these variables are in the mineralization and salinization processes. The matrix also reveals a negative association between calcium and total hardness and magnesium, explaining why these parameters change in opposite directions. Calcium contributes very little to water hardness, as evidenced by the minimal association between calcium and hardness. In their work on water quality assessment in coastal aquifers, (Qin et al., 2013) found that the very low correlations between hydrogen carbonate and calcium and magnesium confirm the salinity in the aquifers.

\subsubsection{Principal component analysis (PCA)}

The PCA yielded two factorial axes that capture the important information needed and allow the point cloud to be represented in a considerable way (75.6\%). The eigenvalues, variances expressed for each factorial axis, and cumulative values are shown in Table 6. The most important factor, $F 1$, is defined by total hardness $(r=0.89)$, magnesium ions $\mathrm{Mg}^{2+}(r=0.86)$, hydrogen carbonates $\mathrm{HCO}_{3}{ }^{-}(\mathrm{r}=0.73)$, and total alkalinity $(\mathrm{r}=0.53)$, essentially characterized in the positive portion and calcium $\mathrm{Ca}^{2+}(\mathrm{r}=-0.34)$ in the negative part (Figure 7). The contact of groundwater with rock formations is what causes the hardness of the water. Magnesium $\left(\mathrm{Mg}^{2+}\right)$ is created primarily by rock modification and acid hydrolysis of silicate minerals. Indeed, the samples were taken from aquifers with fissures and poor water circulation. In this instance, the water can stay in the rock for longer and so achieve chemical equilibrium. The interaction process between water and rock mass is the major factor regulating the variability of the origin of groundwater mineralization, as shown by the factorial axis F1. As a result, it reflects the method of water mineralization acquisition.

Alkalinity total $(\mathrm{r}=-0.54)$, hydrogen carbonate $\mathrm{HCO}_{3}{ }^{-}(\mathrm{r}=-0.51)$, and calcium $(\mathrm{r}=-0.74)$ constitute the negative component of the factor F2, whereas magnesium $(r=0.41)$ and total hardness $(r=0.068)$ define the positive part. The salinization process is the key factor determining the variability of groundwater quality, as shown by the negative grouping of the significant variables (hydrogen carbonate and alkalinity) on this factorial plane. Salinity is linked to natural and anthropogenic processes such as seawater intrusion, calcite dissolution, dolomite, and agricultural wastewater discharges (Marin Celestino et al., 2019). Because of the different observations' contributions to the definition of the main factors, it was feasible to identify which observations are most significant in defining each factor. The samples (W5, W6, $\mathrm{W} 7, \mathrm{~W} 8, \mathrm{~W} 9, \mathrm{~W} 10, \mathrm{~W} 11, \mathrm{~W} 13$, and $\mathrm{W} 15)$ are exposed to the water-rock interaction 
mechanism, as shown in Figure 8. The salinization process has an impact on the samples (W1, W2, W3, W4, W12, and W14).

\section{Discussion.}

\subsection{Groundwater potential zones.}

In a GIS context, the layers were converted to vector format and associated using the Analysis Tools extension with Overlay (Union). The groundwater potential indices were then calculated using equation (7) in ArcGIS software's Field Calculator. Figure 9 depicts a chart of the Campo area's groundwater potential. The groundwater potential indices were split into four groups: low $14.4 \%\left(389.6 \mathrm{~km}^{2}\right)$, moderate $53.3 \%\left(1484.5 \mathrm{~km}^{2}\right)$, high $28.3 \%\left(783.3 \mathrm{~km}^{2}\right)$, and extremely high $4.1 \%\left(110.9 \mathrm{~km}^{2}\right)$. The groundwater potential map is divided into three main geographical areas: very low and moderate in the east, high in the middle, and extremely high in the west. The low to moderate groundwater potential areas are a result of the very steep slopes in these areas, which prevent precipitation from infiltrating the aquifer, as well as the nature of the bedrock, which is characterized by the charnockitic suite, which covers about 44.3 percent of the region's total area. The Charnockitic is the oldest geological unit in the studied area, which could explain the region's high lineament density. The high groundwater potential zone in the research area's center is mostly owing to high lineament densities, very low drainage densities, and gneiss-dominated lithology in these places. Coastal locations in the region have a relatively high groundwater potential, despite modest lineament density along the coast. The significant groundwater potential reported along the sea could be attributed to the lithology of these places, which is characterized by alluvial deposits, as well as the extremely low slopes.

\subsection{Validation of groundwater potential zones.}

The same data that was used to evaluate the groundwater potential map should not be utilized to construct it. To ensure the validity of this analysis, data from various boreholes was overlaid on the groundwater potential map. For the validation of the groundwater potential map, fifteen boreholes were employed. Three boreholes with an average operating discharge of $1.3 \mathrm{~m}^{3} / \mathrm{h}$ are found in very high groundwater potential zones. Six boreholes with an average operating discharge of $1.2 \mathrm{~m}^{3} / \mathrm{h}$ are placed in high groundwater potential zones. Five boreholes with an average operating discharge of $1.2 \mathrm{~m}^{3} / \mathrm{h}$ are placed in the moderate groundwater potential zones. In the low potential zone, one borehole with a $1.5 \mathrm{~m}^{3} / \mathrm{h}$ operating discharge is identified. The gradient descent approach was used to generate a linear regression between the groundwater potential indices and borehole data, with a coefficient of determination $(R=-0.55)$ (Fig.10). In 
the crystalline basement, verifying the map with the flow rates of the boreholes collected in the field might be problematic since a borehole with a high flow rate can be near to a borehole with a low or dry flow rate. The mapping of groundwater potential areas in the Campo region is particularly significant and helpful to the residents, as it can help with effective groundwater development.

\subsection{Sensitivity analyses.}

\subsubsection{Map removal sensitivity analysis.}

The average variation index of the map removal sensitivity analysis is presented in Table 7 . The parameter with the largest order of influence on the groundwater potential map, according to this study, is lithology (LI), which has an average variation index of $3.06 \%$. This could be since this thematic layer is given a lot of weight. LULC has the lowest normalized weight of all the layers, yet it has a $2.31 \%$ average variation index. This demonstrates that the sensitivity of a layer is not always determined by its weight. LI > DD > LULC > LD > IR > SL are the variation indices in order of influence on the potential map.

\subsubsection{The single parameter sensitivity analysis.}

Table 8 shows the average effective weights of the single parameter sensitivity analysis. We may compare the effective weights and the theoretical weights ascribed to the different layers using the single parameter sensitivity analysis. The most effective parameter is lithology (LI), which has an average effective weight of $25.8 \%$ less than its theoretical weight (35.6\%). With an effective weight of $5.81 \%$, LULC is the least effective parameter for the single parameter sensitivity analysis. On the groundwater potential map, the average effective weights are LI > DD $>$ IR $>$ DL $>$ SL > LULC in order of effectiveness.

\subsection{Assessment of groundwater quality.}

PCA was used to find borehole-to-borehole similarities and connections between physicochemical variables. Our findings reveal two mechanisms related to mineralization origins and sources. The alteration of rocks as a result of groundwater's residence time in the rocks causes a process of interaction between water and rock. The process of salinization is attributable to anthropogenic activities, seawater intrusion and wastewater infiltration. There is salinity in the Campo area's groundwater, although the source of this salinization is more tied to human activity than to seawater incursion. This may be in accordance with the work of (Aretouyap et al., 2020). This could be in line with the findings of a geospatial and statistical analysis of the lineaments conducted in the region of Kribi-Campo to better understand the impact of the lineaments on seawater intrusion in the region. According to their findings, 
salinity in groundwater due to seawater intrusion is moderate in the Campo area and very high in the Kribi area due to seawater intrusion. Agricultural operations, domestic wastewater discharge, and industrial wastewater discharge all have a greater impact on salinity. Groundwater quality must be assessed to protect a region's population's health. Understanding the origins of groundwater mineralization might help water resource planners make better decisions.

\section{Conclusion}

Because of its proximity to the sea, the Campo region contributes to Cameroon's economic development through its industry and agricultural operations. The identification of locations suitable for fruitful drilling would help to enhance the living standards of the people. The evaluation of groundwater mineralization is vital for the users' health to be maintained. Six layers of remote sensing and conventional data were considered for this study. The groundwater potential map was created using GIS and AHP techniques. The graphic depicts four distinct zones: low (14.4\%), moderate (53.3\%), high (28.3\%), and very high (4.1\%). The efficiency of the results obtained is demonstrated by the linear regression between the groundwater potential indices and borehole data. PCA was used to assess the phenomena that cause salinity in the region's groundwater. Two factorial axes highlight the interaction between water and rock, as well as a salinization process associated to seawater intrusion and anthropogenic activities, according to our findings. The region's groundwater salinity is more closely linked to anthropogenic activity. This research will aid in the identification of regions that are ideal for the implementation of productive drilling. In addition to a better knowledge of the source of salinity in the Campo region's groundwater. The findings of this article will guide future hydrogeological prospecting efforts for drinking water supply in the region.

\section{Acknowledgements}

The authors would like to acknowledge the company China Geo-Engineering Corporation in Cameroon (GSC-CAM) for discharge wells dug for use in this study. The data presented here form a part of the first author's PhD thesis.

\section{Data availability statement}

The data used to support the findings of this study are available from the corresponding author upon request.

\section{References}


Abbasnia, A., Yousefi, N., Mahvi, A. H., Nabizadeh, R., Radfard, M., Yousefi, M., \& Alimohammadi, M. (2019). Evaluation of groundwater quality using water quality index and its suitability for assessing water for drinking and irrigation purposes: Case study of Sistan and Baluchistan province (Iran). Human and Ecological Risk Assessment: An International Journal, 25(4), 988-1005. https://doi.org/10.1080/10807039.2018.1458596.

Abijith, D., Saravanan, S., Singh, L., Jennifer, J. J., Saranya, T., \& Parthasarathy, K. S. S. (2020). GIS-based multi-criteria analysis for identification of potential groundwater recharge zones-A case study from Ponnaniyaru watershed, Tamil Nadu, India. HydroResearch, 3, 1-14. https://doi.org/10.1016/j.hydres.2020.02.002.

Achu, A. L., Thomas, J., \& Reghunath, R. (2020). Multi-criteria decision analysis for delineation of groundwater potential zones in a tropical river basin using remote sensing, GIS and analytical hierarchy process (AHP). Groundwater for Sustainable Development, 10, 100365. https://doi.org/10.1016/j.gsd.2020.100365.

Agyingi, C. M., Abanda, P. A., Fozao, K. F., Njoh, O. A., Epanty, A. F., Tangko, N. C., Kwangkam, F. N., \& Eseme, E. (2019). Geochemistry of Seep and Produced Oil Samples from Southern Cameroon. Journal of Petroleum Geology, 42(2), 193-206. https://doi.org/10.1111/jpg.12731.

Ajay Kumar, V., Mondal, N. C., \& Ahmed, S. (2020). Identification of Groundwater Potential Zones Using RS, GIS and AHP Techniques: A Case Study in a Part of Deccan Volcanic Province (DVP), Maharashtra, India. Journal of the Indian Society of Remote Sensing, 48(3), 497-511. https://doi.org/10.1007/s12524-019-01086-3.

Allafta, H., Opp, C., \& Patra, S. (2021). Identification of Groundwater Potential Zones Using Remote Sensing and GIS Techniques: A Case Study of the Shatt Al-Arab Basin. Remote Sensing, 13(1), 112. https://doi.org/10.3390/rs13010112.

Arefin, R. (2020). Groundwater potential zone identification at Plio-Pleistocene elevated tract, Bangladesh: AHP-GIS and remote sensing approach. Groundwater for Sustainable Development, 10, 100340. https://doi.org/10.1016/j.gsd.2020.100340

Aretouyap, Z., Billa, L., Jones, M., \& Richter, G. (2020). Geospatial and statistical interpretation of lineaments: Salinity intrusion in the Kribi-Campo coastland of Cameroon. Advances in Space Research, 66(4), 844-853. https://doi.org/10.1016/j.asr.2020.05.002. 
Arétouyap, Z., Bisso, D., Nouck, P. N., \& Asfahani, J. (2018). A Coupled Hydrogeophysical Approach to Enhance Groundwater Resources Management in Developing Countries. Conference of the Arabian Journal of Geosciences, 363-365.

Arunbose, S., Srinivas, Y., Rajkumar, S., Nair, N. C., \& Kaliraj, S. (2021). Remote sensing, GIS and AHP techniques based investigation of groundwater potential zones in the Karumeniyar river basin, Tamil Nadu, southern India. Groundwater for Sustainable Development, 14, 100586. https://doi.org/10.1016/j.gsd.2021.100586

Beyene, G., Aberra, D., \& Fufa, F. (2019). Evaluation of the suitability of groundwater for drinking and irrigation purposes in Jimma Zone of Oromia, Ethiopia. Groundwater for Sustainable Development, 9, 100216. https://doi.org/10.1016/j.gsd.2019.100216

Bodrud-Doza, Md., Islam, A. R. M. T., Ahmed, F., Das, S., Saha, N., \& Rahman, M. S. (2016). Characterization of groundwater quality using water evaluation indices, multivariate statistics and geostatistics in central Bangladesh. Water Science, 30(1), 19-40. https://doi.org/10.1016/j.wsj.2016.05.001

Dar, T., Rai, N., \& Bhat, A. (2020). Delineation of potential groundwater recharge zones using analytical hierarchy process (AHP). Geology, Ecology, and Landscapes, 1-16.

Das, S. (2019). Comparison among influencing factor, frequency ratio, and analytical hierarchy process techniques for groundwater potential zonation in Vaitarna basin, Maharashtra, India. Groundwater for Sustainable Development, 8, 617-629.

Dewandel, B., Lachassagne, P., Wyns, R., Maréchal, J. C., \& Krishnamurthy, N. S. (2006). A generalized 3-D geological and hydrogeological conceptual model of granite aquifers controlled by single or multiphase weathering. Journal of Hydrology, 330(1), 260-284. https://doi.org/10.1016/j.jhydrol.2006.03.026

Dhakate, R., Sankaran, S., Kumar, V. S., Amarender, B., Harikumar, P., \& Subramanian, S. K. (2016). Demarcating saline water intrusion pathways using remote sensing, GIS and geophysical techniques in structurally controlled coastal aquifers in Southern India. Environmental Earth Sciences, 75(5), 363. https://doi.org/10.1007/s12665-015-4940-3

Enyegue A Nyam, F. M., Yomba, A. E., Tchikangoua, A. N., Bounoung, C. P., \& Nouayou, R. (2020). Assessment and characterization of groundwater quality under domestic distribution using hydrochemical and multivariate statistical methods in Bafia, Cameroon. Groundwater for Sustainable Development, 10, 100347. https://doi.org/10.1016/j.gsd.2020.100347

FANIRAN, A. (1969). THE INDEX OF DRAINAGE INTENSITY: A PROVISIONAL NEW DRAINAGE FACTOR. 
Fossi, D. H., Djomo, H. D., Takodjou Wambo, J. D., Kouayep Tchoundi, L. C., Deassou Sezine, E., Takam Tchoupe, G. B., \& Tchatchueng, R. (2021). Extraction and analysis of structural lineaments from Mokolo area, North Cameroon, using DEM and remote sensing images, and their influence on drainage morphometric. Arabian Journal of Geosciences, 14(19), 2062. https://doi.org/10.1007/s12517-021-08460-X

Ghorbani Nejad, S., Falah, F., Daneshfar, M., Haghizadeh, A., \& Rahmati, O. (2017). Delineation of groundwater potential zones using remote sensing and GIS-based datadriven models. Geocarto International, 32(2), 167-187. https://doi.org/10.1080/10106049.2015.1132481

Greenbaum, D. (1985). Review of remote sensing applications to groundwater exploration in basement and regolith.

HORTON, R. E. (1945). EROSIONAL DEVELOPMENT OF STREAMS AND THEIR DRAINAGE BASINS; HYDROPHYSICAL APPROACH TO QUANTITATIVE MORPHOLOGY. GSA Bulletin, 56(3), 275-370. https://doi.org/10.1130/00167606(1945)56[275:EDOSAT]2.0.CO;2

Hounsinou, S. P. (2020). Assessment of potential seawater intrusion in a coastal aquifer system at Abomey-Calavi, Benin. Heliyon, 6(2), e03173. https://doi.org/10.1016/j.heliyon.2020.e03173

Ibrahim-Bathis, K., \& Ahmed, S. A. (2016). Geospatial technology for delineating groundwater potential zones in Doddahalla watershed of Chitradurga district, India. The Egyptian Journal of Remote Sensing and Space Science, 19(2), 223-234. https://doi.org/10.1016/j.ejrs.2016.06.002

José, N. G., Loudi, Y., Quentin, Y. A. J., Yem, M., \& Gabriel, N. C. (2021). Characterization of the basement aquifers over Edéa-Kribi corridor using remote sensing and electrical resistivity method-A case study from Central Africa. Arabian Journal of Geosciences, 14(6), 498. https://doi.org/10.1007/s12517-021-06792-2

Joseph Martial, A., Stéphane Pactrick, A., Philemon, Z. Z., Sébatien, O., Théophile, N. M., Giles Abuara, A., \& Joseph, M. O. (2019). The Sangmelima granite-greenstone belts (South Cameroon): Integration of remote sensing and aeromagnetic data for structural interpretation. The Egyptian Journal of Remote Sensing and Space Science, 22(1), 3747. https://doi.org/10.1016/j.ejrs.2018.11.005

Kanagaraj, G., Suganthi, S., Elango, L., \& Magesh, N. S. (2019). Assessment of groundwater potential zones in Vellore district, Tamil Nadu, India using geospatial techniques. Earth Science Informatics, 12(2), 211-223. https://doi.org/10.1007/s12145-018-0363-5 
Kulandaisamy, P., Karthikeyan, S., \& Chockalingam, A. (2020). Use of GIS-AHP tools for potable groundwater potential zone investigations-A case study in Vairavanpatti rural area, Tamil Nadu, India. Arabian Journal of Geosciences, 13(17), 866. https://doi.org/10.1007/s12517-020-05794-w

Kumar, S., \& Sangeetha, B. (2020). Assessment of ground water quality in Madurai city by using geospatial techniques. Groundwater for Sustainable Development, 10, 100297. https://doi.org/10.1016/j.gsd.2019.100297

Kumar, T., Gautam, A. K., \& Kumar, T. (2014). Appraising the accuracy of GIS-based Multicriteria decision making technique for delineation of Groundwater potential zones. Water Resources Management, 28(13), 4449-4466. https://doi.org/10.1007/s11269014-0663-6

Loh, Y. S. A., Akurugu, B. A., Manu, E., \& Aliou, A.-S. (2020). Assessment of groundwater quality and the main controls on its hydrochemistry in some Voltaian and basement aquifers, northern Ghana. Groundwater for Sustainable Development, 10, 100296. https://doi.org/10.1016/j.gsd.2019.100296

Marín Celestino, A. E., Martínez Cruz, D. A., Otazo Sánchez, E. M., Gavi Reyes, F., \& Vásquez Soto, D. (2018). Groundwater Quality Assessment: An Improved Approach to K-Means Clustering, Principal Component Analysis and Spatial Analysis: A Case Study. Water, 10(4), 437. https://doi.org/10.3390/w10040437

Marín Celestino, A. E., Ramos Leal, J. A., Martínez Cruz, D. A., Tuxpan Vargas, J., De Lara Bashulto, J., \& Morán Ramírez, J. (2019). Identification of the Hydrogeochemical Processes and Assessment of Groundwater Quality, Using Multivariate Statistical Approaches and Water Quality Index in a Wastewater Irrigated Region. Water, 11(8), 1702. https://doi.org/10.3390/w11081702

Masoud, A. A., El-Horiny, M. M., Atwia, M. G., Gemail, K. S., \& Koike, K. (2018). Assessment of groundwater and soil quality degradation using multivariate and geostatistical analyses, Dakhla Oasis, Egypt. Journal of African Earth Sciences, 142, 64-81. https://doi.org/10.1016/j.jafrearsci.2018.03.009

Muangthong, S., \& Shrestha, S. (2015). Assessment of surface water quality using multivariate statistical techniques: Case study of the Nampong River and Songkhram River, Thailand. Environmental Monitoring and Assessment, 187(9), 548. https://doi.org/10.1007/s10661-015-4774-1

Muralitharan, J., \& Palanivel, K. (2015). Groundwater targeting using remote sensing, geographical information system and analytical hierarchy process method in hard rock 
aquifer system, Karur district, Tamil Nadu, India. Earth Science Informatics, 8(4), 827842.

Murmu, P., Kumar, M., Lal, D., Sonker, I., \& Singh, S. K. (2019). Delineation of groundwater potential zones using geospatial techniques and analytical hierarchy process in Dumka district, Jharkhand, India. Groundwater for Sustainable Development, 9, 100239. https://doi.org/10.1016/j.gsd.2019.100239

Nasir, M. J., Khan, S., Zahid, H., \& Khan, A. (2018). Delineation of groundwater potential zones using GIS and multi influence factor (MIF) techniques: A study of district Swat, Khyber Pakhtunkhwa, Pakistan. Environmental Earth Sciences, 77(10), 367. https://doi.org/10.1007/s12665-018-7522-3

Ndema Mbongue, J. L., Ngnotue, T., Ngo Nlend, C. D., Nzenti, J. P., \& Cheo Suh, E. (2014). Origin and evolution of the formation of the Cameroon Nyong Series in the western border of the Congo Craton. Journal of Geosciences and Geomatics, 2(2), 62-75.

Nguiya, S., Mouzong Pemi, M., Tokam, A. P., Ngatchou Heutchi, É., \& Lemotio, W. (2019). Crustal structure beneath the Mount Cameroon region derived from recent gravity measurements. Geoscience $\quad$ Proceedings, 351(6), 430-440. https://doi.org/10.1016/j.crte.2019.05.001

Qin, R., Wu, Y., Xu, Z., Xie, D., \& Zhang, C. (2013). Assessing the impact of natural and anthropogenic activities on groundwater quality in coastal alluvial aquifers of the lower Liaohe River Plain, NE China. Applied Geochemistry, 31, 142-158. https://doi.org/10.1016/j.apgeochem.2013.01.001

Saaty, T. L. (1990). How to make a decision: The analytic hierarchy process. European Journal of Operational Research, 48(1), 9-26. https://doi.org/10.1016/0377-2217(90)90057-I

Saranya, T., \& Saravanan, S. (2020). Groundwater potential zone mapping using analytical hierarchy process (AHP) and GIS for Kancheepuram District, Tamilnadu, India. Modeling Earth Systems and Environment, 1-18.

SCHUMM, S. A. (1968). Speculations Concerning Paleohydrologic Controls of Terrestrial Sedimentation. GSA Bulletin, 79(11), 1573-1588. https://doi.org/10.1130/00167606(1968)79[1573:SCPCOT]2.0.CO;2

Serebryakova, M., Veronesi, F., \& Hurni, L. (2015). Sine wave, clustering and watershed analysis to implement adaptive illumination and generalization in shaded relief representations. The 27th International Cartographic Conference. Rio de Janeiro: ICA. 
Serele, C., Pérez-Hoyos, A., \& Kayitakire, F. (2020). Mapping of groundwater potential zones in the drought-prone areas of south Madagascar using geospatial techniques. Geoscience Frontiers, 11(4), 1403-1413. https://doi.org/10.1016/j.gsf.2019.11.012

Singh, L. K., Jha, M. K., \& Chowdary, V. M. (2018). Assessing the accuracy of GIS-based Multi-Criteria Decision Analysis approaches for mapping groundwater potential. Ecological Indicators, 91, 24-37. https://doi.org/10.1016/j.ecolind.2018.03.070

Sinha, M. K., Verma, M. K., Ahmad, I., Baier, K., Jha, R., \& Azzam, R. (2016). Assessment of groundwater vulnerability using modified DRASTIC model in Kharun Basin, Chhattisgarh, India. Arabian Journal of Geosciences, 9(2), 98. https://doi.org/10.1007/s12517-015-2180-1

Soyaslan, İ. İ. (2020). Assessment of groundwater vulnerability using modified DRASTICAnalytical Hierarchy Process model in Bucak Basin, Turkey. Arabian Journal of Geosciences, 13(21), 1127. https://doi.org/10.1007/s12517-020-06101-3

Takodjou Wambo, J. D., Ganno, S., Djonthu Lahe, Y. S., Kouankap Nono, G. D., Fossi, D. H., Tchouatcha, M. S., \& Nzenti, J. P. (2018). Geostatistical and GIS analysis of the spatial variability of alluvial gold content in Ngoura-Colomines area, Eastern Cameroon: Implications for the exploration of primary gold deposit. Journal of African Earth Sciences, 142, 138-157. https://doi.org/10.1016/j.jafrearsci.2018.03.015

Tchameni, R., Mezger, K., \& Nsifa, E. N. (1996). Geochemical and Nd-Sr isotope composition of the Archean Ntem granitoids (Southern Cameroon): Origin and source characterisation. Réunion Des Sciences de La Terre, 16. http://pascalfrancis.inist.fr/vibad/index.php?action=getRecordDetail\&idt=6312976

Teikeu Assatse, W., Njandjock Nouck, P., Tabod, C. T., Akame, J. M., \& Nshagali Biringanine, G. (2016a). Hydrogeological activity of lineaments in Yaoundé Cameroon region using remote sensing and GIS techniques. The Egyptian Journal of Remote Sensing and Space Science, 19(1), 49-60. https://doi.org/10.1016/j.ejrs.2015.12.006

Teikeu Assatse, W., Njandjock Nouck, P., Tabod, C. T., Akame, J. M., \& Nshagali Biringanine, G. (2016b). Hydrogeological activity of lineaments in Yaoundé Cameroon region using remote sensing and GIS techniques. The Egyptian Journal of Remote Sensing and Space Science, 19(1), 49-60. https://doi.org/10.1016/j.ejrs.2015.12.006

Tepoule, N., Kenfack, J. V., Ndikum Ndoh, E., Koumetio, F., \& Tabod Tabod, C. (2021). Delineation of groundwater potential zones in Logbadjeck, Cameroon: An integrated geophysical and geospatial study approach. International Journal of Environmental Science and Technology. https://doi.org/10.1007/s13762-021-03259-5 
Tsaffo Mbognou, M. H., Assomo Ngono, G. S., \& Fossi, D. H. (2021). GIS, Remote Sensing and Analytical Hierarchy Process-Based Identification of Groundwater Potential Zones in Mokolo, Northern Cameroon. International Journal of Multidisciplinary and Current Research, 9, 224-232.

Yeh, H.-F., Cheng, Y.-S., Lin, H.-I., \& Lee, C.-H. (2016). Mapping groundwater recharge potential zone using a GIS approach in Hualian River, Taiwan. Sustainable Environment Research, 26(1), 33-43. https://doi.org/10.1016/j.serj.2015.09.005

\section{Figure caption.}

Figure 1. Location map of the study area.

Figure 2. Ombrothermal diagram.

Figure 3. The flow chart depicting the approach used in this research.

Figure 4. Groundwater is influenced by geological, topographical, hydrological. (a) Lithology, (b) Lineament's density, (c) Infiltration rate, (d) Drainage density maps, (e) Slope, (f) Land use / Land cover maps.

Figure 5. The research area's spatial distribution of physicochemical parameters. (a) total hardness, (b) total alkalinity, (c) calcium, (d) magnesium, (e) hydrogen carbonate.

Figure 6. Matrix showing correlations between several physicochemical properties.

Figure 7. Relationships between physicochemical parameters are represented by correlation circles.

Figure 8. Graphical representation of physicochemical parameters and groundwater samples from the study area.

Figure 9. The AHP model generated a groundwater potential map.

Figure 10. Relationship between groundwater potential index and well discharge. 


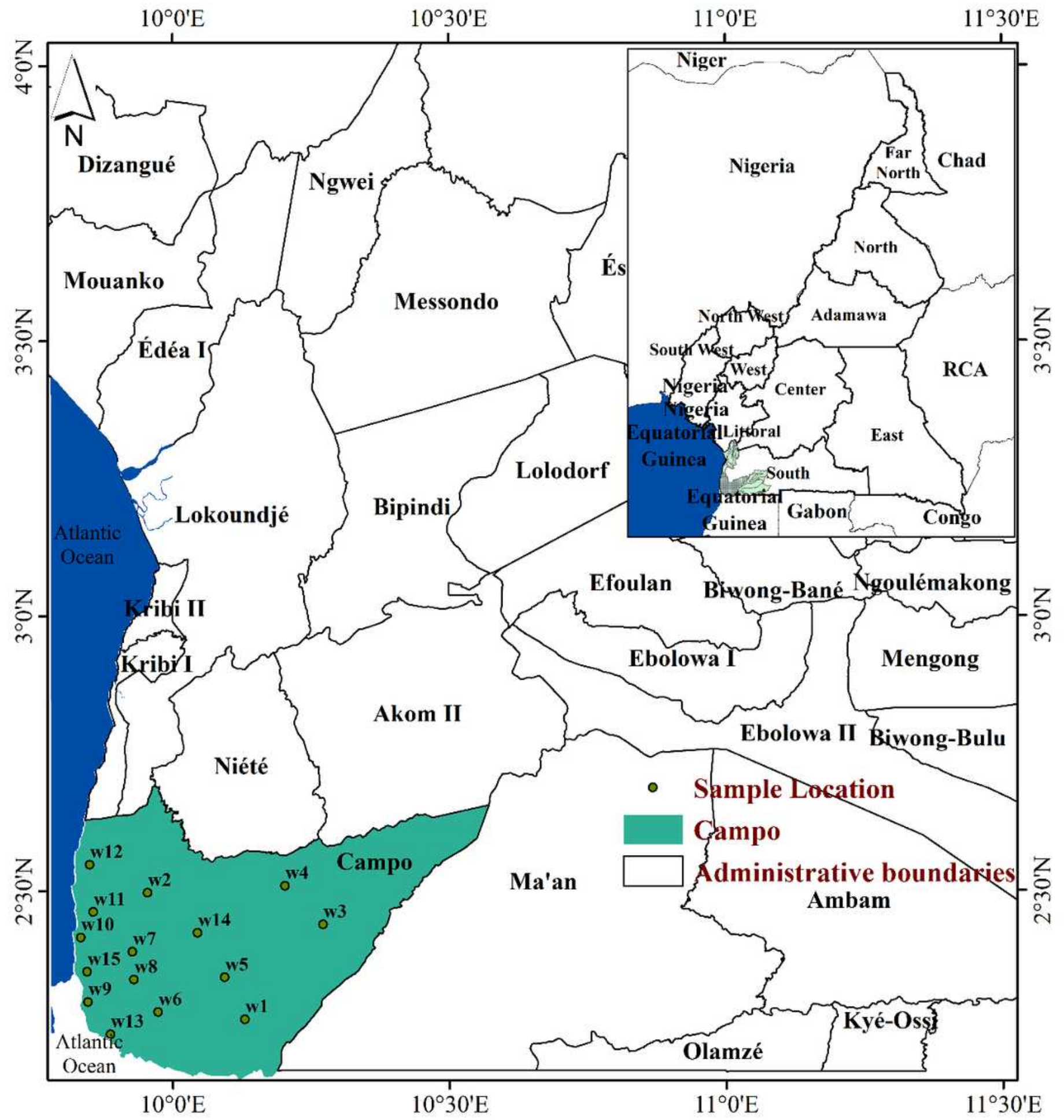

Figure 1

Location map of the study area. 


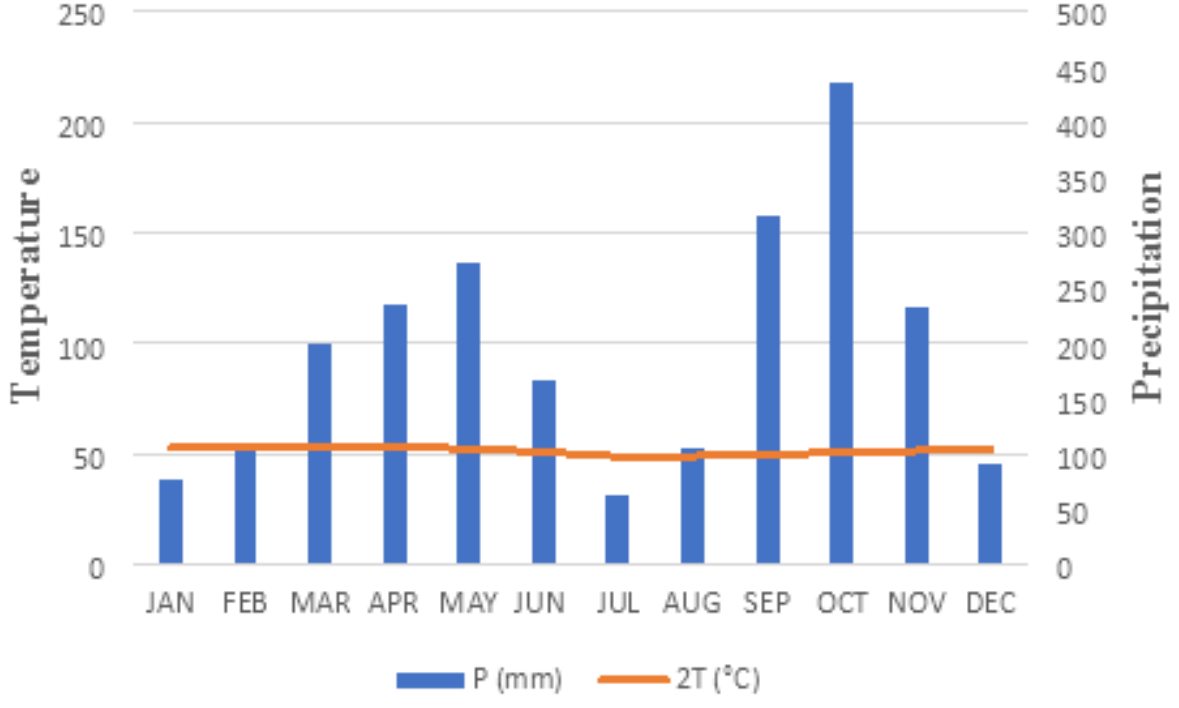

Figure 2

Ombrothermal diagram.

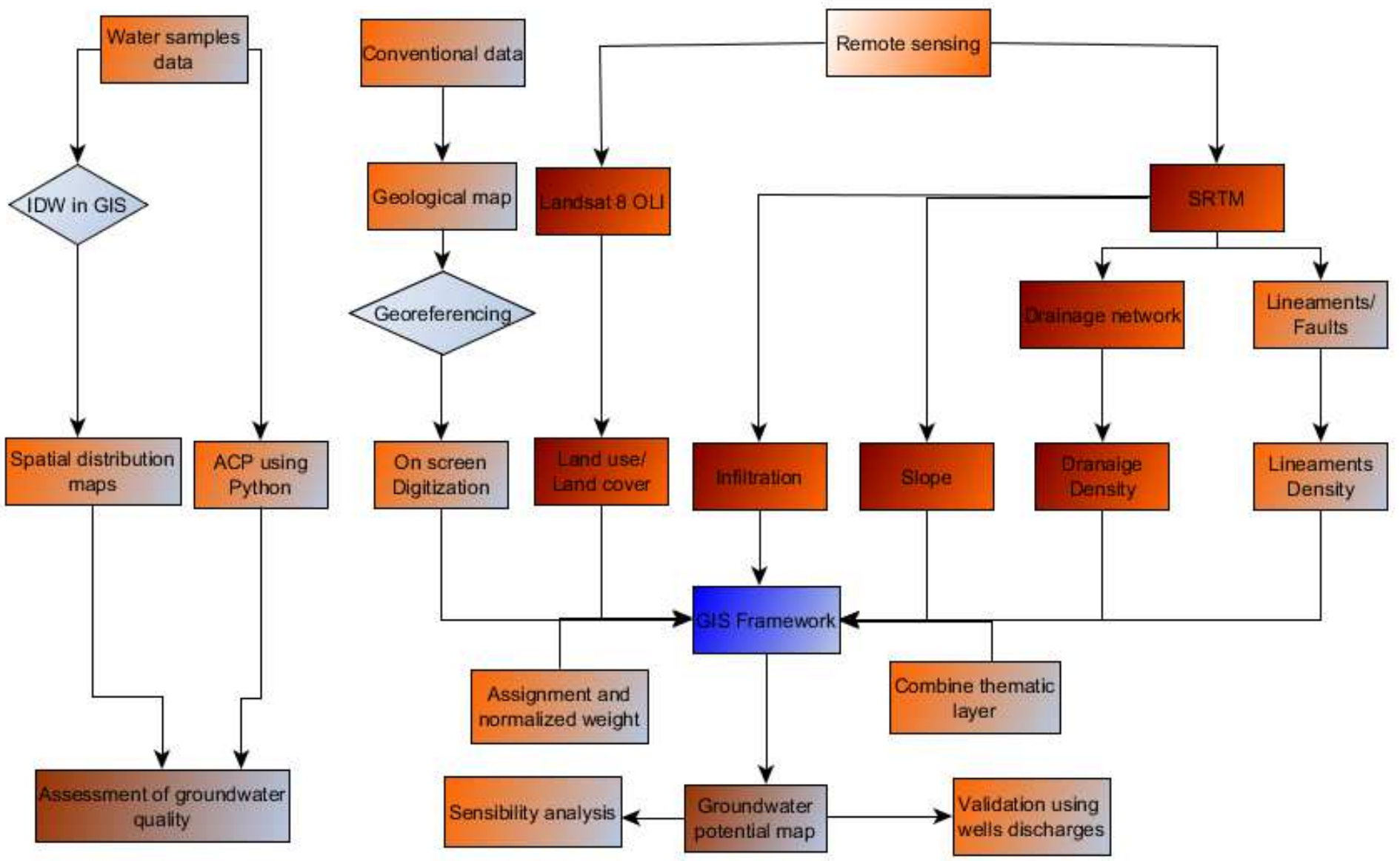

\section{Figure 3}

The flow chart depicting the approach used in this research. 

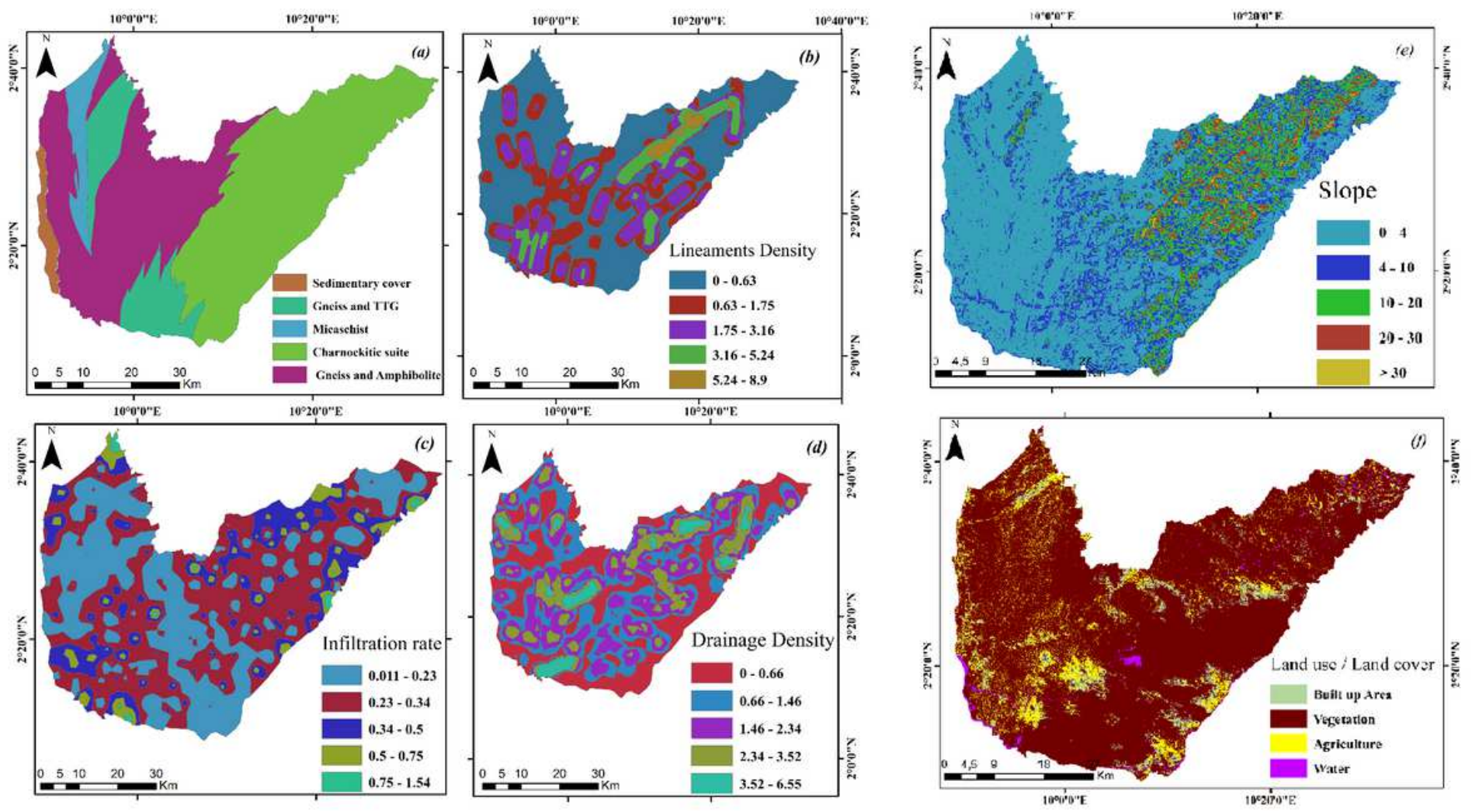

Figure 4

Groundwater is influenced by geological, topographical, hydrological. (a) Lithology, (b) Lineament's density, (c) Infiltration rate, (d) Drainage density maps, (e) Slope, (f) Land use / Land cover maps. 

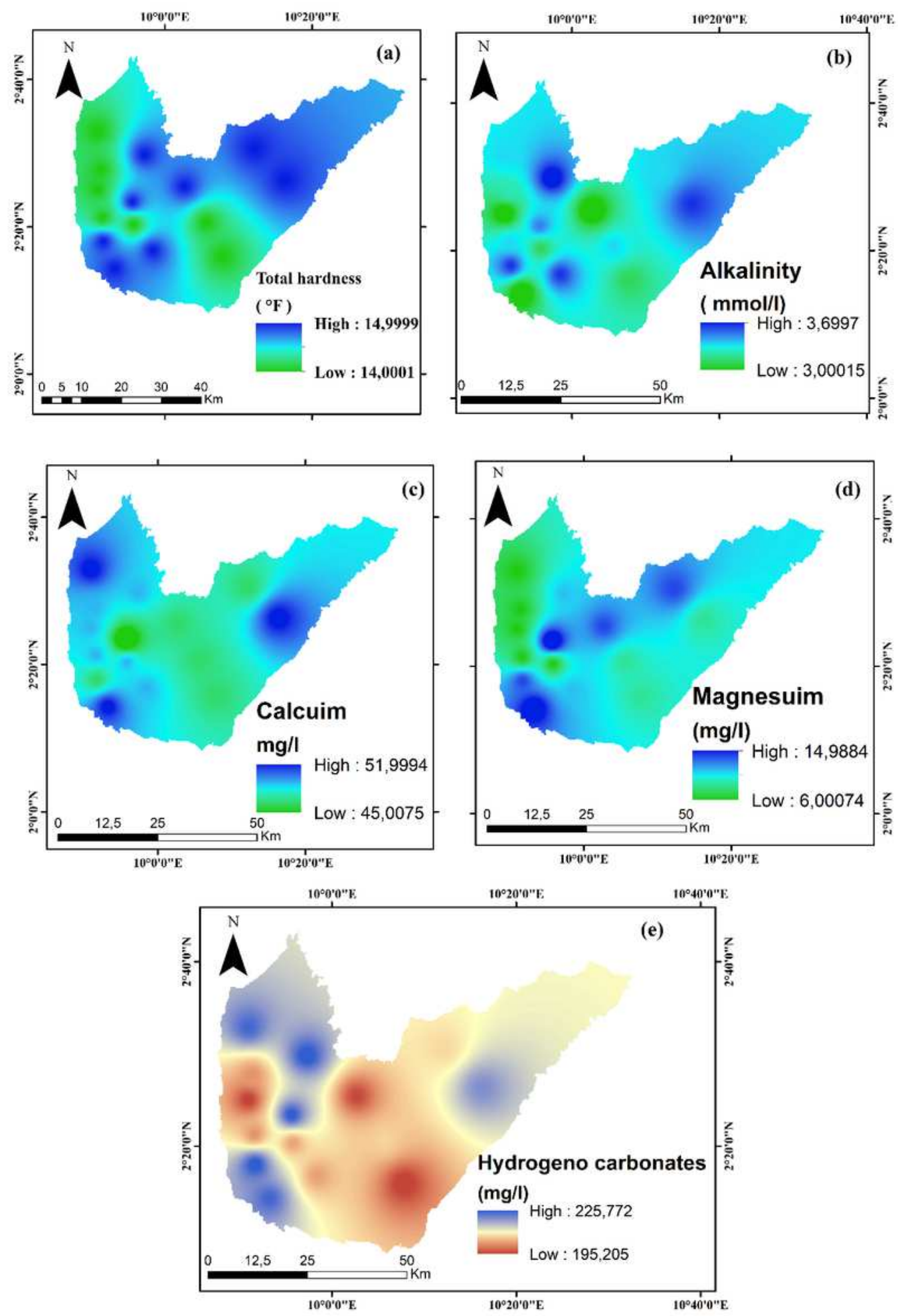

\section{Figure 5}

The research area's spatial distribution of physicochemical parameters. (a) total hardness, (b) total alkalinity, (c) calcium, (d) magnesium, (e) hydrogen carbonate. 


\section{Correlation Heatmap}

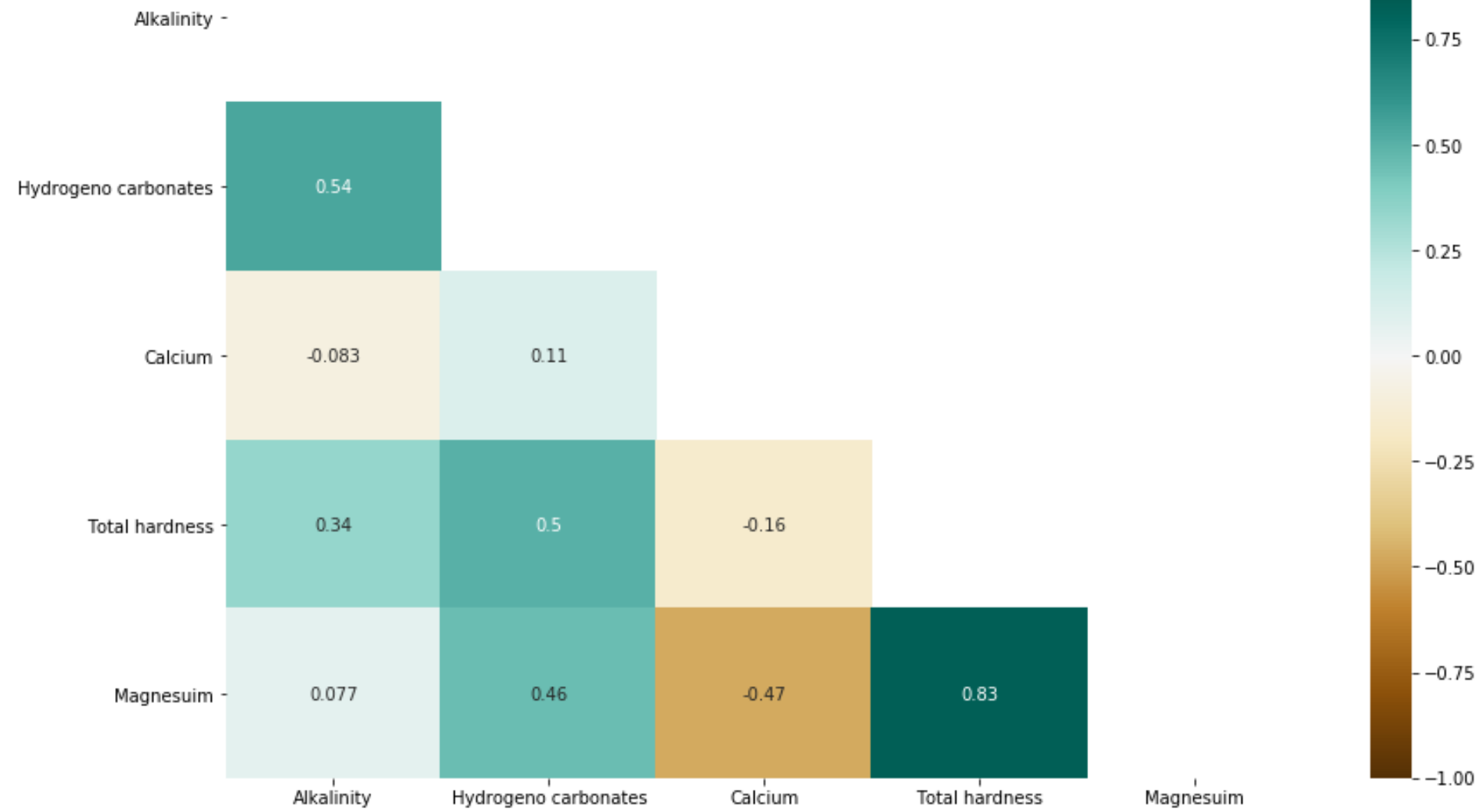

Figure 6

Matrix showing correlations between several physicochemical properties. 


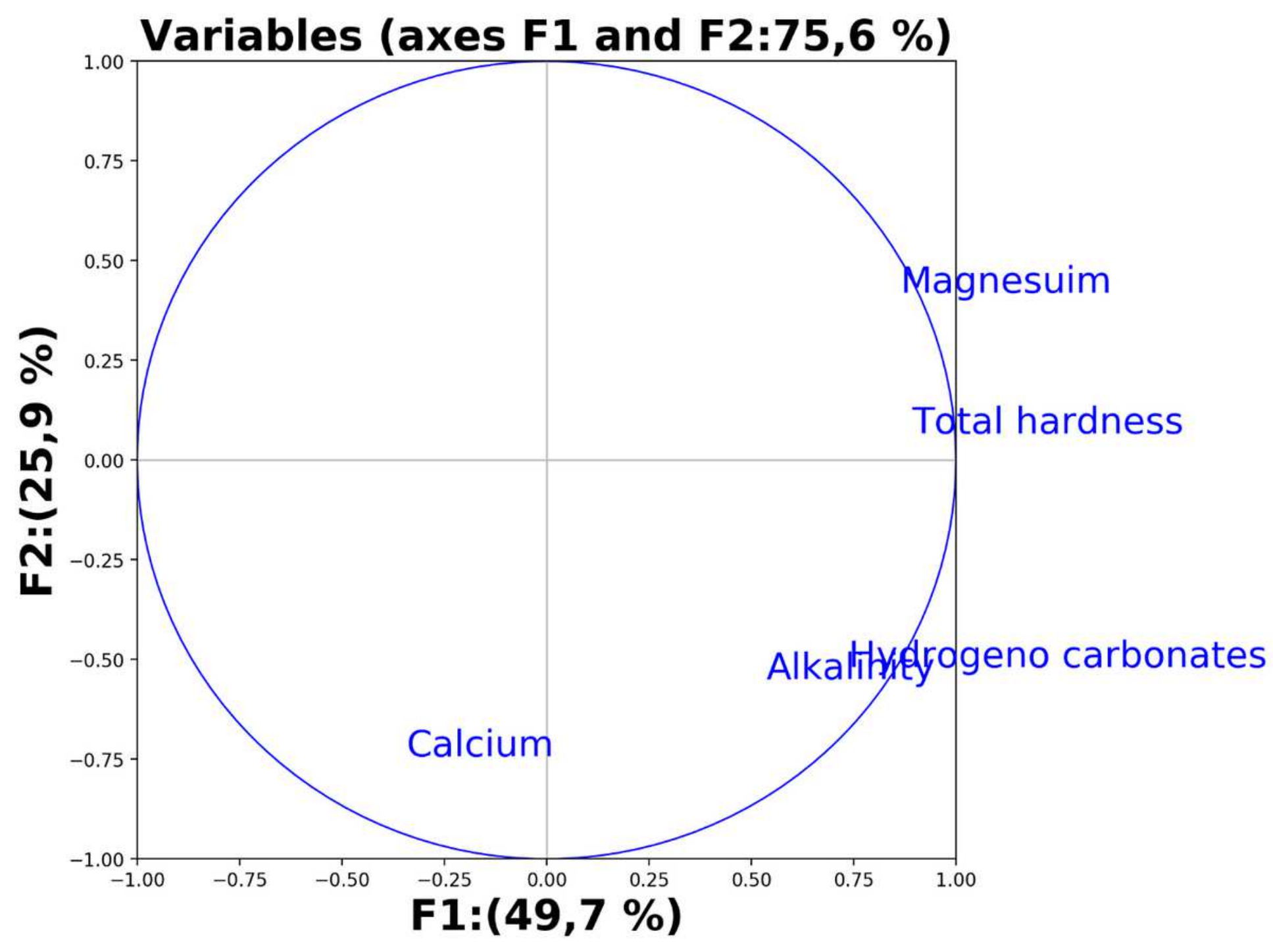

Figure 7

Relationships between physicochemical parameters are represented by correlation circles. 


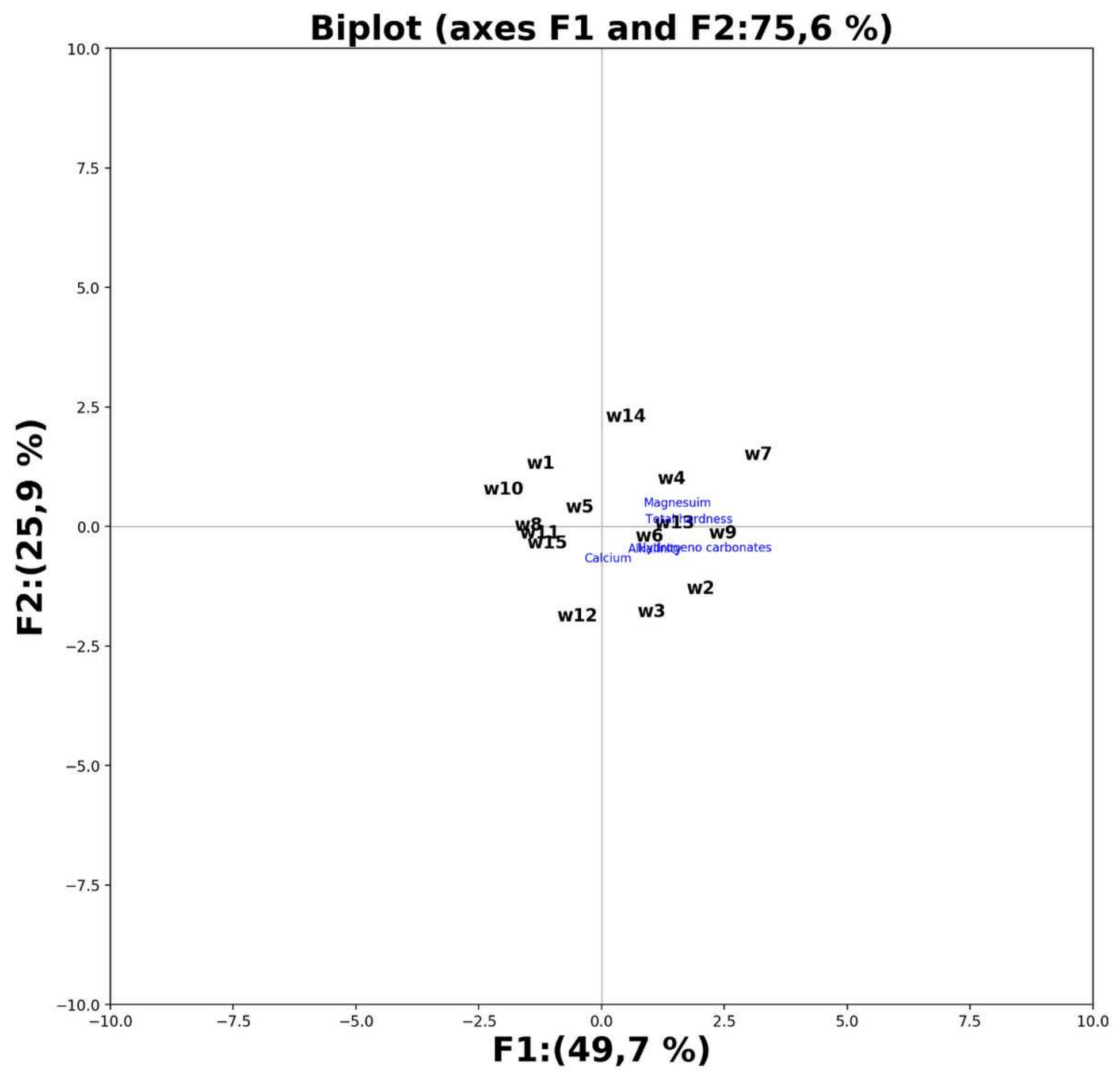

Figure 8

Graphical representation of physicochemical parameters and groundwater samples from the study area. 


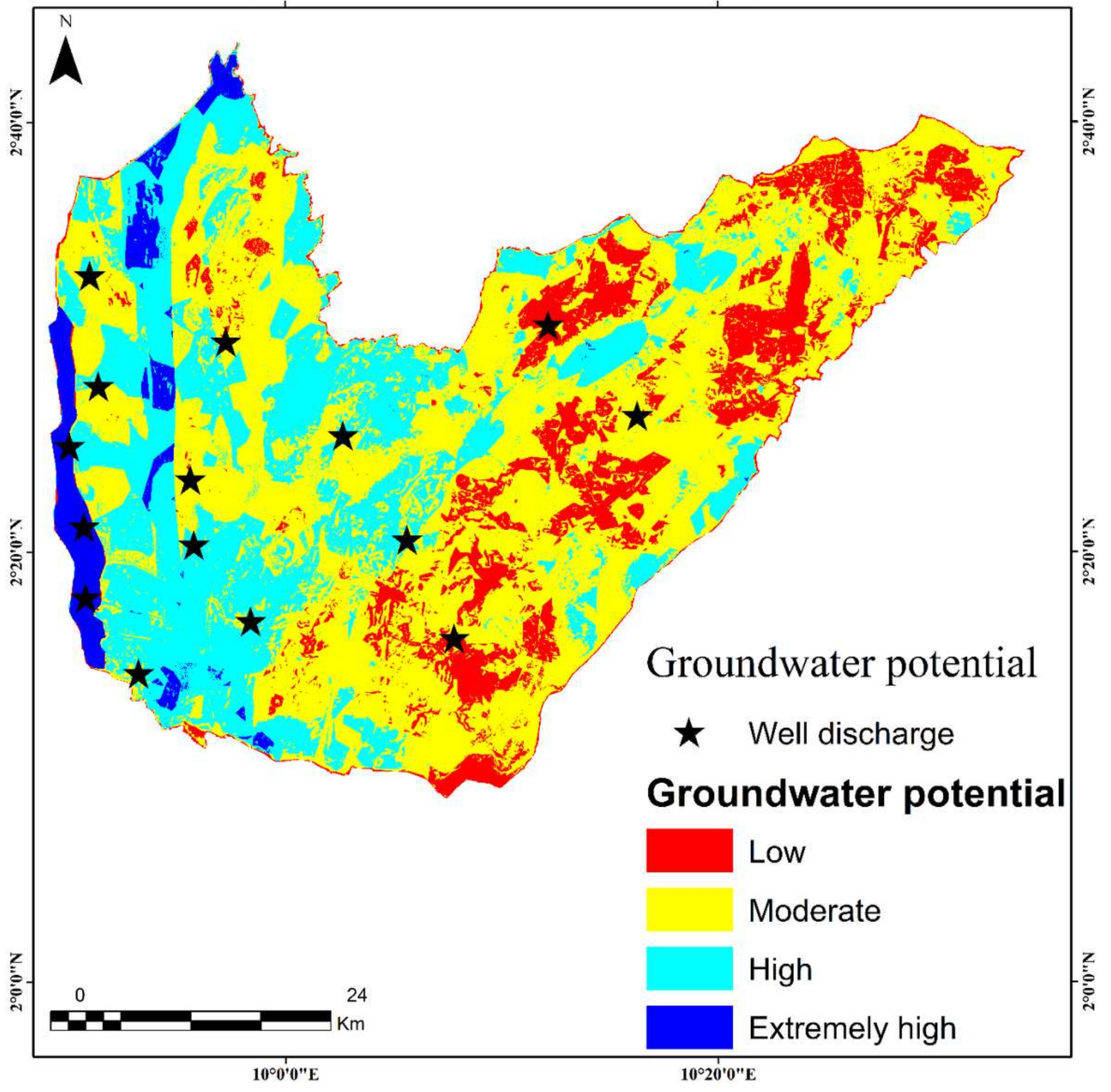

Figure 9

The AHP model generated a groundwater potential map. 


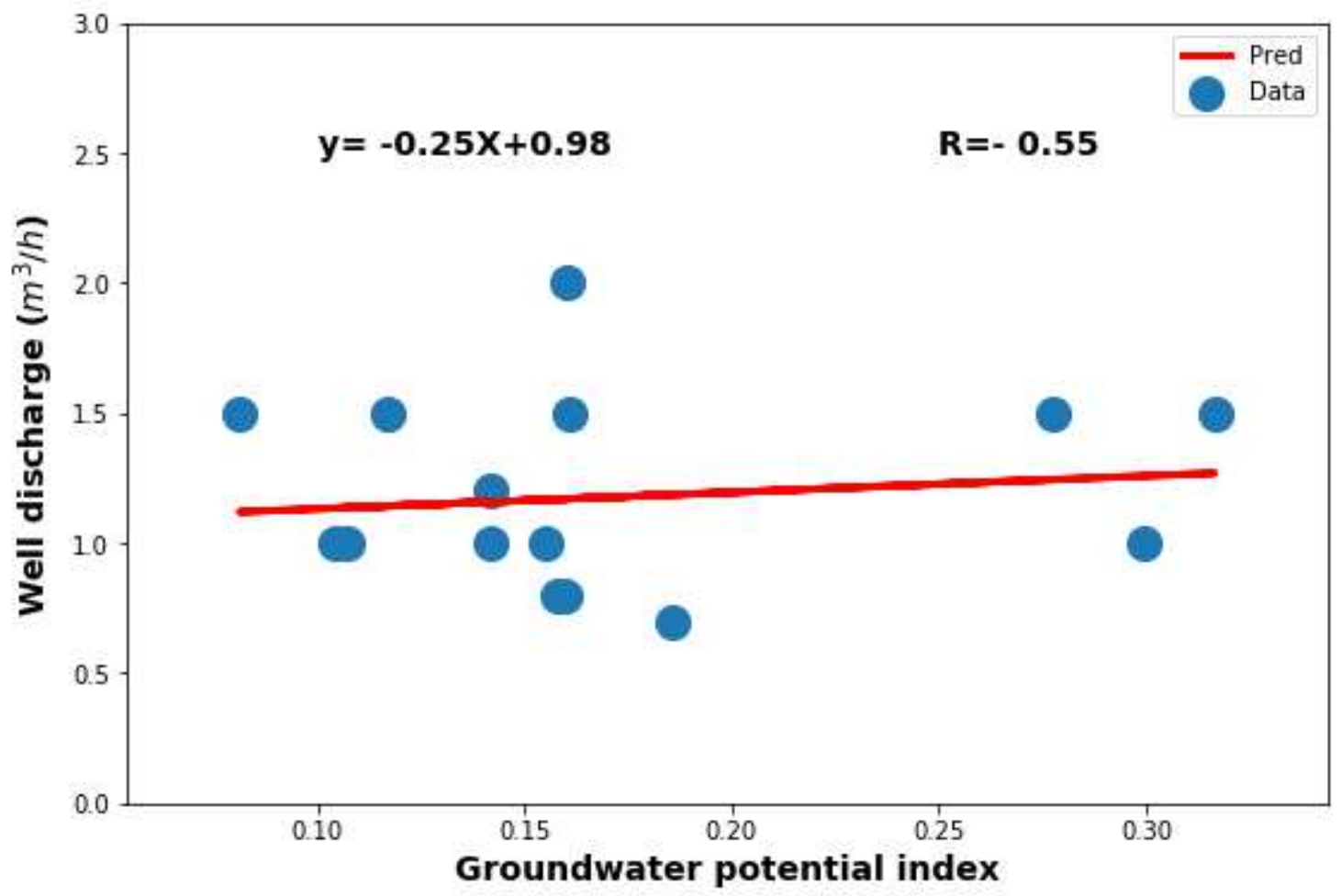

Figure 10

Relationship between groundwater potential index and well discharge. 